\title{
Proverb and style in Eminescu's journalistic writings
}

\author{
Ioan Milică ${ }^{\circledR \star}$ \\ Faculty of Letters, "Alexandru Ioan Cuza" University, Bd. Carol I 11, 700506 Iaşi, Romania
}

\section{Article info}

History:

Received October 27, 2019

Accepted November 3, 2019

Published November 7, 2019

Key words:

text linguistics

stylistic analysis

journalistic writing

Mihai Eminescu

\begin{abstract}
The paper inquires into the idea that Mihai Eminescu (1850-1889)—the most important Romanian writer of the $19^{\text {th }}$ century-used in his journalistic writings proverbs collected from the speech of common people. Concerning the hundreds of proverbs featured in the press articles penned by Eminescu, I assume that the aforementioned writer naturalised in the mosaic-like journalistic texts certain book excerpts upon which he conferred the stylistic image of folk elements. Without denying that some of the proverbs used by the poet in his articles pertain to common language, in this study, I am mainly interested in the "stage setting" orchestrated by the writer to confer a folkloric aura upon erudite excerpts. Last but not least, the study unveils Eminescu's willingness to experiment with various journalistic compositional formulas, tailored to his knowledge, sensibility, and imagination.
\end{abstract}

\begin{abstract}
Motto: "quid, quaso, probabilius quam quod nemo non dicit? Quid verisimilius, quam id, qoud tot atatum, tot nationum consensus et velut idem suffragium comprobauit?"

["what could be more convincing, I ask you, than what is said by everyone? What is more likely to be true than what has been approved by the consensus, the unanimous vote as it were, of so many epochs and so many people?"]
\end{abstract}

(Erasmi Roterodami, Adagiorum chiliades tres, 1508)

\section{Preliminary remarks}

We know today that Eminescu was a proverbial spirit. Taking into account the harmonic effects of the journalistic texts, gifted commentators such as Perpessicius (1983, p. 411) focused on the fascination that proverbs appealed to the poet's musical sense. They showed that the sequences of wise words that Eminescu highlights in some articles have an æsthetic fund, in the sense that they reflect the beauty of a folk literary universe sentenced to oblivion, which the journalist restores. Others-on a more speculative tone-underlined the attraction for the "plasticity of proverbs" as evidence of the "theoretical and practical" interest for the paremiological treasure (Eminescu, 1980, p. 44; Oprea, 1983, p. 99). From this perspective, Eminescu would have been - just like Ion Creangă-a tireless explorer of folklore.

Seemingly convincing, the appraisals focusing on the esthetical, rhetoric and pragmatic resonances of the proverbs - displayed in Eminescu's journalistic writings - fail to feature, however, the setting in which the writer creates a poetics of the proverb. In order to brush the dust off this picture and to save it from oblivion, it is necessary to provide an insight into the cultural history of the proverbs; but before taking that route, it is also worth exploring the idea that Eminescu would have been a proverb collector. Without denying that the writer collected folklore, it is more important to observe the benefits brought by that activity to Eminescu's writings. Instead of reprising the cliché that the poet collected from the common people wise words that he subsequently used in his creation, I believe it is more effective to discuss certain proofs that clarify the impact of Eminescu's encounter with the enigmatic world of proverbs.

\footnotetext{
^Email address: ioanister@gmail.com.
} 


\section{The proverbial Eminescu}

Around 1868-as Ștefan Cacoveanu remembers-the poet, a prompter at the National Theatre of Bucharest at that point, had wise words to say about the risks of literary debut. "One of us had the unfortunate idea of having his poems printed. Eminescu made so much fun of it! The poems were rather low quality. [... W With his deep, but sweet tone, sometimes he talked as if he were teaching. He used to say, "Getting published is no joke. I have often been sorry of publishing what I published. There is an old saying «The mouth should have three locks: in the heart, in the throat and the third on the lips: when you let a word out of your heart, make sure it does not break the other lock; once you let the word out of your mouth, a horse, a hound or even a hawk won't be enough to catch it». You need to ponder on a work a hundred times before having it published" (Cioabă, 2013, p. 98).

The person who had his poems printed was Ioniță Scipione Bădescu, one of the Transylvanian students within the Vienna circle and a future editorial colleague of Eminescu. Actually, the "old saying" uttered on a teacher's tone was not a proper folk saying, but an excerpt from the famous book Archirie și Anadan, which circulated in the Romanian cultural space from the 17th century. It had been printed in 1850 in Anton Pann's edition ${ }^{1}$ : "My son, when you wish to talk to your prince, put three gates on your word: a gate in the heart, another one in the throat, the third one in the mouth. Pay attention to the third gate, for if you let your word out, a horse, a hound or even a hawk won't be enough to catch it; as you speak it, it gets loose" (Georgescu, 1997, p. 159). There is no way of knowing whether the poet collected the formula from the speech of simple people, which is little plausible, if he memorised the fragment from the famous Oriental story, or if it was ascribed to him by Ștefan Cacoveanu, thus turning the writer into a character no different from a literary hero. More likely than the aforementioned assumptions is the observation that Pann (1963, II, p. 27) imitated ${ }^{2}$ the famous Oriental story in his wonderful collection of proverbs, as observable in fragments such as this one: "The word is like the wind, a stallion or even a hound fails to catch it." Included by Zanne in the anthology titled Proverbele romanilor ([Proverbs of the Romanians], 10 volumes, 1895-1903), Anton Pann's simile was regarded as a sample of peasant wit, despite its obvious erudite origin; hence, subsequent editors included it in the collections of folk proverbs (Muntean, 1984, [2738], p. 104).

The certainty that Eminescu possessed, however, the rhetorical gift of proverbiality comes from another source, too, namely the memoirs of Theodor Ștefanelli. He recounts that in 1875-namely the year when in Chernvitsi the officials prepared to celebrate 100 years of "annexing Bukovina to Austria"Eminescu came to the city without a warning. He brought along several hundred copies of a leaflet titled "Bukovina abducted", which he had smuggled illegally across the border, in a "humungous wooden chest", full of "many old books, psalm copies, breviaries, bibles" and other "torn papers". Asked about the purpose of carrying around such a large chest full of old imprints, Eminescu replied in German, das beste kommt zuletzt, thus showing that the subversive publication had been hidden under the pile of old pages, in order to avoid raising suspicion among the customs officers (Ștefanelli, 1914, p. 150). He who laughs last laughs best, the poet seems to convey to his old school companion. In such a context, the use of the German proverb serves not that much for a demonstration of Eminescu's communication skills in Goethe's language, but to highlight that proverbs are meant to reveal the importance of an authentic

\footnotetext{
${ }^{1}$ In the version published by Pann (1963, III, p. 12), the fragment was altered: "When you want to talk to somebody, take your word out through three locks: one to your heart, the second to your throat, and the third one to your lips; for should the «word come through your mouth, it will fly like the wind, and no stallion or hound will catch it»".

${ }^{2}$ The text known among Romanians as Archirie și Anadan has a cultural history with ancient origins, being subsumed to Oriental sapiential literature. In relation to the long and complicated manuscript tradition of the text, the typographer Anton Pann took quite daring editorial decisions, from turning passages into poem lines to ignoring certain fragments. As a literary source, Archirie si Anadan played a rather important role in the Romanian culture of the $19^{\text {th }}$ century. "Many of Archirie's maxims were reprised in C. Negruzzi’s short story, Păcală și Tândală. Anton Pann, who processed Archirie’s novel, also enriched his collection of proverbs (Povestea vorbii) with elements loaned from Archirie; other adages of the Assyrian author have interesting parallels in a Zanne's collection" (Cartojan, 1974, I, p. 323).
} 
event. Ultimately, they depict the world as a stage.

The poet's letters also highlight his occasional preference for the proverbs in which the image as fruit of fantasy and the dense thought as fruit of reflection complement each other. In the summer of 1882, the editor of "Timpul" - caught in the sweltering heat of Bucharest-sends to Veronica Micle a letter complaining about his poor state of mind and the difficult task of handling the newspaper's contents by himself. For the sake of his partner-whom he encourages - he chases away his dark thoughts by adopting a sapiential style familiar to illustrious letter-writers: "Eh! La pauvreté est une mauvaise chose! And I see no way of escaping it once and for all, not for the moment. But, anyway, God is good, devil's the master. After rain comes sunshine, which will be even brighter through you, Nică" (Zarifopol-Illias, 2000, [71]). In the middle of the letter, the grain of hope expressed as a proverb dissipates its rhetoric force. However, it allows us to understand that Eminescu does not simply reprise the proverb, like a drawing imprinted on a background; he actually uses it as a discrete but effective way to concise meditation. This style of contemplating the world through the lens of a string of proverbs is as old as the dawns of writing in the cultural history of humanity. In the $19^{\text {th }}$ century literature, the Romanian writers admired by Eminescu feature it: Costache Negruzzi, Anton Pann, Ion Creangă. Hence, in Povestea lui Harap-Alb (1877), when Smooth Face, the evil character, orders the hero to bring "heads of lettuce" from the Bear's Garden, HarapAlb runs to the stables and starts complaining to his trusted companion, the enchanted stallion, as he regrets not having considered his parent's advice. More resilient than his master, the stallion encourages the hero with the following words: "Master, hold fast, for gently like the wind I'll fly and take you round the world on high. Great is God and quick is the devil. To be sure we shall settle accounts with that SmoothFace, there's time yet" (Creangă, 1978, p. 255).

Beyond the paremiological resonance between Eminescu's letter and the fairytale of the Moldavian storyteller, it is worth analysing the working technique with the proverb. Emphasised in the literary and the epistolary dialogue, the proverb becomes an emblem of the art of fine writing, as if the necklace of wise phrases spontaneously wrote themselves on paper, just as words naturally come out of a man's lips. Grafted in the painstaking process of writing, this chimera of oral-like communication expands the echoes of speech into the silent dominion of writing. Upon reading, we seem to hear a voice; we suddenly have the feeling that a remote voice whispers to us from behind. In the intimacy of Eminescu's epistolary writing, this effect of eliminating the distance encompasses the flow of consciousness, the momentary experience, the electrifying release of thoughts into words and, thus, it acquires more affective intensity. An example hereof is the fragment featured below.

"My sweet little Veronica,

It is five in the morning and I, being caught up in work, could not shut my eyes yet. Now, after finishing all of the day's duties, I end it thinking about you, my jolly, joyful and sad bird. I strive to touch you, to kiss your wing... on the spot where two wings used to lie, on your white, beautiful and round shoulder. But I know I won't get my wish, because right now you are sleeping soundly, in your little bed with, I'm sure, fine linen, and here I am looking at the candle and thinking of you. Sleep and don't wake up, my dear Nicuță, for I shall watch over you from here.”

(Zarifopol-Illias, 2000, [43])

\section{Proverbial frames}

Not only the poet's replies and letters, but his manuscripts, too, suggest that the world of proverbs stirred an interest that cannot be circumscribed strictly to the sphere of concerns related to the collecting of folklore. More likely, it reflects the enormous work done by Eminescu to adjust the high temperatures of the erudite culture to the common reading horizon entailed by the press articles addressed to an educated audience. Furthermore, even back when he was in college, the poet-a devoted newspaper and magazine 
reader $^{3}$ - realised that the journalistic trend during his time in Vienna displayed an intellectual style, infused with book references and allusions. Thus, it was different from the eclectic and imitative rhetoric characteristic to the first waves of Romanian newspapers. In Romania, journalistic writing becomes professional in the second half of the $19^{\text {th }}$ century, mostly between 1860 and 1880 . In this context, a writer with extraordinary experimental affinities, such as Eminescu, practices a wide repertory of editorial formulæ, from news to pamphlets, from investigation to feuilleton. Hidden in the mosaic matrix of his texts, the pleasure of cultivating aphorisms, allusions, citations, puns, maxims, proverbs or sayings is related to the incandescent core of Eminescu's writing. This led to the conclusion that the writer made the expressive virtues of the folk language blossom in the journalistic field (Andriescu, 1979, p. 158). In fact, Eminescu's journalistic style proves to be-in the history of the Romanian press-an inimitable artefact, a vivid emblem of the author's creativity, world-view and personality.

For Eminescu, the proverbs have-if we take into account the notes taken during his studies at the University of Berlin-the value of spiritual etymon ${ }^{4}$. Considered from the angle of ethnopsychology, parœmias reflect the way of being in case of common people: "The wit and wisdom of a people, the profound and sharp spirit of observation, the hard-working character, the saying, fantasy and even authentic style of humour-all of them reflect in the proverb" (Eminescu, 1993, p. 639). Upon accepting that the proverbial wisdom of the folk can reveal the touches of a portrait of the collective mindset, in the sense that they would allow an outline of the personality traits making up the psychological profile of a nation, Eminescu uses a triple frame-philosophical, ethical and æsthetic-to insert his view of the identity of proverbs.

The philosophical frame is based on the considerations and commentaries revealing that a proverb is a fact of knowledge encrypted in the conventional symbols of a certain language. In other words, the proverb is a simple form of access to wisdom, given that love for wisdom, i.e. philosophy is-according to the writer- "setting the world's being into notions, for the determination of which judgment uses no other authority than its own" (Eminescu, 1993, p. 20). The textual miniatures called proverbs are samples of thought and language that include-just like photographs-impressions and opinions about episodes within the kaleidoscope of reality (Norrick, 1985, p. 16). Their philosophical appeal resides in the tension between the amplitude of thoughts and the landforms of the real; hence, any proverb signals from a critical stance the relation between thought and event. A proverb such as Si tacuissesphilosophus mansisses-cited by Eminescu in his articles (Eminescu, 1984, p. 202; 1985, p. 30)_proposes a well-grounded ontological framework, according to the grammar of the adage, on crediting unreality: «had you shut up, you would have remained a philosopher, but that did not happen». Moreover, the formal concision of proverbs contrasts with the meaning depths that they explore. Consequently, they may not be ascribed a certain value of truth; on the contrary, they are relative statements which-within the same set of paremiological representations-may be in antithesis (Mieder, 1993, p. X).

The crystallisation and shortness of the form entail several strategic communicative advantages. Easy to memorise, easy to use and quick to process, proverbs have a great adaptive potential, given that they often have to rely on other contexts than those in which they were created. Such potential also involves the level of form and the level of meaning. The diversity of usage reveals why proverbs are not fixed structures, as we are too often taught to believe. On the contrary, they are living texts, circulating in various communication mediums. As such, they display a phonic, grammatical and lexical variation (Krikmann, 1985, p. 75).

In the ethical frame - as words of wisdom-proverbs outline a spectre of human qualities and flaws

\footnotetext{
3"Reading German newspapers and journals was a permanent occupation of the poet and anything but random. It may be stated without exaggerating that it was truly dominant in his intellectual formation. This fact is not that surprising if we take into account the information and scientific level of the periodicals in those times, which could play a much more important role than nowadays, when there are other mass information means" (Frisch, 1999, I, p. 20).

${ }^{4}$ The concept - proposed by Spitzer (1970, p. 54, 60) — reveals the internal vital core of a work of art. In the present study, the notion highlights the role of proverbs in the stereotypical portrayal of human types.
} 
that they comment from a typological angle. The human types depicted in proverbs-whether those in a positive light (honest, hard working, wise, sincere) or those portrayed in negative colours (hypocrite, lazy, crazy, liar) - make up a model empirically composed of similarities and differences. Each paremiological character is depicted through typical situations where the proverbial quality or flaw is highlighted. Thus, the focus is on the category that a real individual could illustrate when others discuss about him by using the sapiential formula. Hence, in Romanian proverbs, and not only in such texts, the lazy is usually portrayed as idle, indolent, poor, cunning or not keeping his word, while the hard working man is seen as a measured, wealthy, just, merciful or serious homesteader. Between the antipodes-laziness and hard work - there are definitely intermediary hues, but the notional and imagistic universe of the proverbs is prone to strikingly contrasting, unequivocal polarisations. The similarity and contrast relations between the constitutive units of a paremiological system - constructed as a constellation of conceptual and textual spheres related to one another-may also be considered equations. This is what Eminescu does when he notes that the proverbs are moral equations: "Moral equations in the proverb: Each person has his good side and his bad side. The good of the bad. The bad of the good. Chacun a les défauts de ses vertus et les vertus de ses défauts. Any propensity to one side corresponds to an absence, to an ascending trend for the other side. The admirable discourse of Marc Anthony does not comprise an equation, I wonder? Does not any subtle calumny that begins by praising the enemy comprise an equation? Maiorescu's habit. Do not thesis and antithesis-a worm in the sea that loves a star-comprise an equation? A worm on the bottom of the sea in love with a star" (Eminescu, 1993, p. 330).

The note highlights not only that a human type is depicted by comparison with other types-a mechanism that justifies why aurea mediocritas imprints the course of thought, action and behaviour often recommended in proverbs - but also that by contrastive relations, paradoxical associations may emerge, with a definite artistic potential. An artist with such a pronounced sense of contrasts like Eminescu must have realised the certain rhetoric power held by sources such as maxims, aphorisms and proverbs.

The asthetic frame must comprise the interpretation of the proverb as a literary fact and not as a mere act of communication. Is the proverb a literary object? It is so, beyond a doubt. The historical and philological study of the cultural productions of ancient civilisations shows that-from time immemorial-a distinct type of writings emerged, subsequently called by the specialists sapiential literature. In Ancient Sumer, this corpus comprised five categories of texts: a) proverbs; b) miniature essays; c) instructions and precepts; d) didactic fragments and e) disputes and debates (Kramer, 1951, p. 28). Other specialists extended the text base by including in the field of sapiential literature the fable, riddles, parable or satire (Gordon, apud Murphy, 1981, p. 9). The first proverbs reported by scholars as certain date to four millenniums and a half ago. According to the inscriptions on the clay tablets imprinted with cuneiform writing, the Sumerian language-the oldest written language of humanity-seems to have gotten out of use in the second millennium BC, being in competition with Akkadian, a Semitic language cognate of Hebrew, Aramaic, Syriac and Arabic. The hundreds of proverbs written initially in Sumerian and subsequently in Akkadian are the oldest literary texts in the world. They were used in scribal education and-by contents-they reflect the lifestyle and worldview of the Sumerians (Alster, 1997, I, p. xix). Equally important as their double origin - folk and erudite - is the series of expressive traits characteristic nowadays to parœmias, maxims and adages: brief character; generic use of the grammatical person; parallelism and presence of expressive procedures specific to proverbs: metaphor, irony, comparison, hyperbole, metonymy and synecdoche (Gordon, 1968, p. 10-20).

Some of the Bible books -included by specialists in the sphere of sapiential literature ${ }^{5}$ - resonate with the literary fund of ancient Mesopotamia (Murphy, 1981, p.3). Furthermore, it is worth highlighting that

\footnotetext{
${ }^{5}$ The phrase sapiential literature was first crystallised in Biblical studies, and then it was also exploited to name several categories of texts within the literature of ancient Mesopotamia. In the studies dedicated to the sapiential books of the Scripture, mainly Job, Proverbs and Ecclesiastes, some researchers make the difference between two literary genres: 1 . the saying, with three species: the proverb, the experiential saying and the didactic or erudite saying; 2. commands and prohibitions (Murphy, 1981, p. 3-6).
} 
the Scripture represents one of the great sources of proverb making in the Christian world. In Europe, to this source, one can identify three more paremiological circulation pathways: a) loans from one nation to another, b) medieval Latin, and c) classic Greco-Latin literature (Mieder, 2004, p. 10-13). The proverbial thesaurus of each Christian nation includes between 300 and 500 proverbs of biblical origin (Mieder, 1990, p. 12). We add that the paremiological heritage of Antiquity was conserved in the great medieval and Renaissance anthologies of proverbs and adages-being subsequently formalised in several cultures due to the great circulation of compilations such as Floarea darurilor (Fiore di virtu). It thus becomes clear that Eminescu's fascination for the ancient literature of proverbs reflects the intuition that-though these miniature texts-one may access and restore an archaic worldview. For the poet, the universe of the proverbs is the archæological site where one may seek the literary remains of an old thought lost.

On such grounds, Eminescu's glossary of proverbs and idiomatic constructs published in the magna edition initiated by Perpessicius (Eminescu, 1963, p. 363-381) must be seen less as evidence of the writer's efforts to collect the gems of folk wisdom and more as work in the site where the poet tried to restore-for both his own professional needs and their æsthetic value-sapiential items of Romanian circulation. A reliable support for this statement is represented precisely by the glossary compiled by Eminescu, where almost all the 400 paremiological and sentence units are reprised from the great manuscript of wisdom literature penned by Iordache Golescu ${ }^{6}$. The glossary also comprises excerpts from the collection of proverbs by Anton Pann, also known as Povestea vorbii [The Tale of the Wit]. In other words, the poet stylised the erudite sources, aiming to confer upon book excerpts the mask of folk elements.

\section{Proverb and style in Eminescu's newspaper articles}

In order to understand how the journalist exploits the book excerpts to confer them a folkloric aura, we can take as example the feature article published in the newspaper Timpul of October $31^{\text {st }}$, 1879 . This text-where the editor-poet enters a polemic with the liberal gazettes Românul and Presa on the topic of repurchasing the railways - features excerpts already reprised and copied in the notebook. It was as if, upon writing the article, Eminescu had the glossary with him and would had chosen-with the carefulness of an artist - the proverbial items most suitable for this textual mosaic:

"No sooner had we had the chance to say that on principle the Conservatives were not against repurchasing, than "Românul" and the personal body of the great political leader took this opportunity to deduce the monstrosity that we would agree with the repurchasing project. Potato, potahto, Tomato, tomahto (my italics, I.M.). Namely, want it or not, they get ahead of us and say that we want the project as it is.

However, with permission from the body of Russian agents and from the great political leader, we must tell them that one is not the same as two (my italics, I.M.). For repurchasing, on principle the Lascar Catargiu government gave consent. If the great political leader Mr. Vasile Boerescu should be so kind as to remember the cause for which he himself quit the cabinet, then the body of the great political leader would easily see that he left because he would turn the repurchasing into a gheșeft, which the old Lascar Catargiu rejected ardently.

Well, without further ado, things are as follows. During the Catargiu cabinet, the still stakeholders-deceived, in their turn, by Mr. Stroussberg and by our Pătărlăgeni and Costinești, as our people was deceived, and burdened by the many debts they had to make in order to save the railways-propose to the government to convert the assets into state titles. They also propose to give the ownership of the railway to the state. An equitable conversion-namely with the stakeholders incurring the losses of breaching contract-could be good for the country. Material benefits would not be essential-because a just an equitable transaction would not lead to great

\footnotetext{
${ }^{6}$ The full title of the work is Pilde, povățiri i i cuvinte adăvărate și povești adunate dă dumnealui dvornicul Iordache Golescul, ful răposatului banul Radul Golescul (ms. 213, cf. CMR, I, 62).
} 
amounts-but the moral benefit that the state as new owner of the railway would have opened new opportunities for many people. I refer here to the occasion to learn practical topics and to work on the railways and steam machines skilfully instead of spending their time in petty political games and bland journalistic pieces.

Namely, this was an honest idea from the beginning, and it could not have been otherwise, given that a political leader, not even a lawyer, would be in charge of it.

This was not, however, the main concern of the great political leader.

He founds quickly the Bank of Bucharest, with the sole purpose of buying himself assets and of selling them subsequently to the state, for a 300 percent profit, for the great political leader was a Foreign Affairs minister.

Then he was made to understand-subtly, of course, given that for the great political leader noblesse oblige- that he may not be the Bank of Bucharest and a minister at the same time. Hence, he was made to choose between the two.

Thus, he chose the Bank of Bucharest and he became part of the opposition. From the moment when-as a minister and a speculator at the same time-he could no longer repurchase, the freedom, nationality and all the other abstract nouns were compromised. (...).

Thus, to resume the main idea, the Bank of Bucharest was as bankrupt as could be. Hence the "centre", the union with the reds-with whom anything is possible; hence, the "nationality, freedom, justice" in "Românul". This paper, instead of "Become enlightened and you'll exist", should have written the maxim of Mr. Buescu: "Self comes first" (my italics, I.M.).

This is why we believe the repurchase to be a matter of trust.

We already had the Bank of Bucharest in the Council of Ministers; we do not want to see it today, too. The Conservatives first had the "repurchase" in their programme, hence we are the godfathers, and "the godfather pays, the godfather decides" (my italics, I.M.).

Therefore, I will say it like it is. This is a racket, a low racket, a racket specific to the Bank of Bucharest. (...).

The beautiful precedent of the Bank of Bucharest does make us doubt the enciphered arguments of the government, which I wish to decipher, to prevent it from becoming Nastratin's trade (author's italics, I.M.). Besides the State as owner, all the people who prefer to take their assets and to take their dividends throughout ninety years will remain owners. These people will be entitled to be members of the general assembly, members in the representations of these assemblies. In one word, they will participate to everything: they will have the cake and eat it (my italics, I.M.), thus a permanent intruder in the Romanians' houses. (...).

Thus, considering the elements making up the reds and the aggravating circumstance of the former Bank of Bucharest, I repeat that trust is the main issue. Repurchase-yesterday bad and today good-is hard for people to understand. Then we know that the devil does not build churches (author's italics), so the reds never did anything good for this country. This repurchaseaccording even to Dim. Sturza, who proposed it—will lead to financial disaster."

(Eminescu, 1989, p. 341-343)

In the poet's collection, the string of proverbs, sayings and proverbial allusions featured in this paper shows the order in which they were extracted from the great manuscript compiled by Iordache Golescu ${ }^{7}$. Among the units registered in the edition of the Opere, at numbers from 339 to 349, one reads the texts Mai aproape dinții ca părinții (339), Milă de silă, dor de zor (340), Dracul nu face biserici (345) and Și din coș grăunțe, și din postavă tărîțe, și din fäină parte și din traistă merinde (349). Another proverbial excerpt, Una-i una, două mai mult, is featured at number 108: the order within the glossary shows that they were selectively copied from the source-manuscript. For instance, the units from 1 to 116 are reprised from

\footnotetext{
${ }^{7}$ For the historical presentation of the circumstances in which Eminescu managed to get his hands on this manuscript of lessons, advice and stories, see Perpessicius (1954, p. 27-28), reprised in Golescu (1990, p. 369-375).
} 
"Pilde i tîlcuirea lor" (Golescu, 1990, p. 165-176), while the units from 285 to 316 are from the chapter "Pentru om". Another loaned saying, Nastratin's trade, inventoried under number 358-reprised either from Golescu's anthology or from Anton Pann-is used in several articles.

By including in the introductory part of the article the paremiological element Milă de silă, dor de zor (Potato, potahto, tomato, tomahto) is meant to stir the polemic fire, serving as an element to launch the argumentation. The saying Una e una și doua fac mai multe (one is not the same as two) consolidates the legitimacy of the standpoint expressed by the journalist, featured as a "voice" of the community. The allusive processing of the proverb Obrazul subțire cu marecheltuială se tine (noblesse oblige) is meant to turn the parœmia into a ferment of bitter irony. The character outlined in the article-the dignitary Vasile Boerescu-is depicted in the colours of human types specific to the world of proverbs, as a two-faced and prodigal man. Invoked in the field of political life, the wedding-like allusions of the proverb Naşul botează, nașul cutează (the godfather pays, the godfather decides) are meant to highlight the superiority of the virile view of Conservatives concerning the liberal programme. Furthermore, the measures taken by the liberals are seen as typical pictures of corruption and greed, underlined by the formula și din coş grăunțe și din fäină parte și din traistă merinde (they will have the cake and eat it). Outlined from the beginning and rhetorically argued throughout the demonstration, the conclusion that the repurchase of railways will be a financial disaster is intensified at the end using a paremiological metaphorising formula. The demonisation of liberal government, "nici diavolul biserici face, nici roșii au adus vrun bine în țara aceasta (the devil does not build churches, so the reds never never did anything good for this country)" is beyond doubt a stylistic artifice for the conservative public of the newspaper. In this part, the use of the proverb plays the expressive role of consolidating in a conclusive manner the reader's adherence to the standpoint expressed in the article.

On the one hand, the opinion expressed by the journalist and the meanings of the proverbs lead to a parallelism that generates reverberations, as if the sapiential formula became the bell from which the words written by the journalist echoed. On the other hand, by using bookish words of wisdom, the journalist creates an effect of archaic peasant orality. This technique of seducing the reader has a poetic foundation, in the sense that the article-though a piece of erudite expression in terms of structure and language-is shaped in such a way as to feature the rhythms and sparkles of folk speech. The setting reflects the attention given to the form embellishing the contents of the message. This setting is consistent with the statement by Ion Slavici concerning the efforts made by Eminescu to make the notions and ideas within his words seem sculpted in the beautiful and clean marble of the people's language:

"Concerning him, the folk style was intentional. While others, such as Creangă, Ispirescu or Ioan Sima wrote using the folk style because-rising from the folk-they remained peasants with some culture and they were not able to write otherwise. Eminescu, who did not rise from the folk, made efforts to match the people as much as possible, because it was the only way to get his message across and to make it long-lasting."

(Slavici, 1998, p. 47)

Thus, we have proof that Eminescu's paremiological glossary is, first of all, a tool used mainly in the field of his journalistic activity, reason for which specialists have used it in order to determine the paternity of certain articles. The only thing left to do now is to appraise the way Eminescu pleads in favour of understanding the proverb as a venerable symbol of identity. The fact that he saw proverbs as a sample of folk thought and art is also visible in an article of January $5^{\text {th }}, 1877$, featured in Curierul de Iaşi. Upon commenting the publication at Piatra Neamț of a periodical, Colectorul literar pentru ambele sexe, Eminescu rejects the trends of translating literary works "without any real value" and he argues for the need to collect folk literature, because it reflects the linguistic and artistic sense of the people.

\footnotetext{
${ }^{8}$ It was not fully edited, but the collection of the dvornic Iordache Golescu was for the most part transcribed by Iuliu Zanne and included in the volumes VIII and XI of his series of Romanian proverbs, while other parts were edited much later.
} 
"The periodicals in the territory could do a huge service to Romanian literature and lexicon. The common language of political newspapers threatens to drown-just like rogue-the field of people's living language. Besides, given the rise of modern realism, we delete legends and stories, proverbs and locutions, true gems of the thought system characteristic to Romanian people. If these periodicals did us the greatest favour by collecting accurately the specific forms of folk thought, they would be priceless. However, these translations from French or German of useless products, who are they meant for? They only underline the false idea that the people, throughout two thousand years, had no language or thoughts, and that the two must be created with artistry by a certain academy."

(Eminescu, 1980, p. 298-299)

This fragment suggests both the consideration of proverbs as forms of thought and language characteristic to "folk thought system" and their understanding as old literary gems. The poet's argument for the conservation of these remains of collective mindset is animated by the belief that modernity rushes the oblivion of archaic linguistic and literary forms, thus leading to the estrangement of modern man. Saving the literary memory of the past would thus mean an effective return to the riverbed of tradition. The dowry of "locutions, proverbs, songs and stories" represents a "wonderful work" that benefited from the contribution of "millions of brains, most of them well trained, and dozens of scholars with common sense and reliable hearing." (Eminescu, 1989, p. 84). In contrast with this enlightened treasure, the present is flooded-in the journalist's opinion-by cosmopolite elements, divergent from folk thought; thus, their ban from daily use should be a duty of educated spirits. For these reasons, the press article should be conceived and read as a tale of the wit, as a vivid spectacle of ideas and words. It is opposed to the dry and cosmopolite language of the journalists and the politicians without ideas, imagination and verb. Ultimately, a journal is a world of paper, and the writer still rules as a sovereign over this empire of letters.

[English version by Alina-Veronica Piftor]

\section{Bibliography}

Alster, B. (1997). Proverbs of the Ancient Sumer, The World's Earliest Proverb Collections, 2 vol., CDL Press, Bethesda, Maryland. Andriescu, Al. (1979). Limba presei românești în secolul al XIX-lea, Editura Junimea, Iași.

Cartojan, N. (1974). Cărțile populare în literatura românească, vol. I. Epoca influenței sud-slave, Editura Enciclopedică Română, București.

Cioabă, C. (ed.) (2013). Mărturii despre Eminescu, Editura Humanitas, București.

CMR = Ștrempel, G. (1978). Catalogul manuscriselor românești. B.A.R. 1-1600, vol. I, Editura Științifică și Enciclopedică, București.

Creangă, I. (1978). Memories of my Boyhood, Stories and Tales, translated by A. Cartianu and R. C. Johnston, București, Minerva.

Eminescu, M. (1963). Opere, vol. VI, Literatura populară. Introducere - Poeme originale de inspirație folclorică - Lirica populară - Balade - Dramatice - Basme în proză - Irmoase - Paremiologie - Note și variante - Anexe - Exerciții \& Moloz - Caetul anonim - Bibliografie - Indices, Editura Academiei R.P.R., București.

Eminescu, M. (1980). Opere, vol. IX, Publicistică, 1870-1877, „Albina”, „Familia”, „Federațiunea”, „Convorbiri literare”, „Curierul de Iași”, Editura Academiei R.S.R., București.

Eminescu, M. (1984). Opere, vol. XI, Publicistică, 17 februarie - 31 decembrie 1880, „Timpul”, Editura Academiei R.S.R., București.

Eminescu, M. (1985). Opere, vol. XIII, Publicistică, 1882-1883, 1888-1889, „Timpul”, „România liberă”, „Fîntîna Blanduziei”, Editura Academiei R.S.R., București.

Eminescu, M. (1989). Opere, vol. X, Publicistică, 1 noiembrie 1877 - 15 februarie 1880, „Timpul”, Editura Academiei R.S.R., București.

Eminescu, M. (1993). Opere, vol. XV, Fragmentarium. Addenda ediției, Editura Academiei Române, București.

Frisch, H. (1999). Sursele germane ale creației eminesciene, 2 vol., Editura Saeculum I.O., București.

Georgescu, M. (ed.) (1997). Archirie și Anadan, în Gheție, I. \& Mareș, Al. (coord.), Cele mai vechi cărți populare în literatura română, vol. II, Editura Minerva, București, 1997, p. 103-169.

Golescu, I. (1973). Proverbe comentate, edited by Gh. Paschia, Editura Albatros, București. 
Golescu, I. (1990). Scrieri alese, edition coordinated by Al. Rosetti, Editura Cartea Românească, București.

Gordon, E.I. (1968). Sumerian Proverbs: glimpses of everyday life in ancient Mesopotamia, Greenwood Press Publishers, New York.

Kramer, S.N. (1951). Sumerian Wisdom Literature: A Preliminary Survey, in "Bulletin of the American Schools of Oriental Research", 122, p. 28-31, Crossref.

Krikmann, A. (1985). Some Additional Aspects of Semantic Indefiniteness of Proverbs, in "Proverbium. Yearbook of International Proverb Scholarship", The Ohio State University, 2, p. 58-85.

Mieder, W. (1990). Not by Bread Alone. Proverbs of the Bible, Shelburne, Vermont, The New England Press.

Mieder, W. (1993). Proverbs are Never out of Season. Popular Wisdom in the Modern Age, Oxford University Press, Oxford.

Mieder, W. (2004). Proverbs: a handbook, Westport, Connecticut, London, Greenwood Press.

Muntean, G. (ed.) (1984). Proverbe românești, Editura Minerva, București.

Murphy, R.E. (1981). Wisdom Literature. Job, Proverbs, Ruth, Canticles, Ecclesiastes, and Esther, William B. Eerdmans Publishing Company, Grand Rapids, Michigan.

Norrick, N. (1985). How Proverbs Mean: Semantic Studies in English Proverbs, Mouton, New York, Crossref.

Oprea, Al. (1983). In căutarea lui Eminescu gazetarul, Editura Minerva, București.

Pann, A. (1963). Scrieri literare, 3 vol., Editura pentru literatură, București.

Perpessicius (1954). Opera folcloristică a lui Iordache Golescu, in "Studii și cercetări de istorie literară și foclor", vol. III, Editura Academiei R.P.R., București.

Perpessicius (1983). Eminescu și folclorul, in “Eminesciana”, Editura Junimea, Iași.

Slavici, I. (1998). Amintiri, Editura Viitorul Românesc, Deva.

Spitzer, L. (1970). Études de style, Gallimard, Paris.

Ștefanelli, T. (1914). Amintiri despre Eminescu, Institutul de Arte Grafice C. Sfetea, București.

Zanne, I. A. (1895-1903). Proverbele românilor din România, Basarabia, Bucovina, Ungaria, Istria și Macedonia, București.

Zarifopol-Illias, C. (ed.) (2000). Dulcea mea Doamnă / Eminul meu iubit. Corespondență inedită Mihai Eminescu - Veronica Micle, Editura Polirom, Iași. 